\title{
'Human Terrain' hits rocky ground
}

The US Army's controversial project for social scientists to serve alongside soldiers on the battlefield has suffered another setback with the loss of its director, retired US Army colonel Steve Fondacaro, who left on 11 June. Although no reason was given for his sudden departure, those familiar with the programme say that it is yet another sign of trouble for a project that has faced criticism since its inception four years ago.

Greg Mueller, a spokesman for US Army Training and Doctrine Command, based in Fort Monroe, Virginia, confirmed that Fondacaro is no longer manager of the Human Terrain System (HTS), but declined to provide details. He says that the army is now looking for a new civilian director. Colonel Sharon Hamilton will run the programme until a new director is found.

Fondacaro said in a phone interview that, although not technically fired, he had been pushed out of the position. He said that there had been "a lot of tension" between himself and senior army leaders, exacerbated by congressional pressure. "This is just a culmination of that," he said.

The HTS aims to help commanders to understand local culture and reduce violence. But critics, including the American Anthropological Association in Arlington, Virginia, see a contradiction between the goal of anthropology, to help local populations, and the goals of the army,

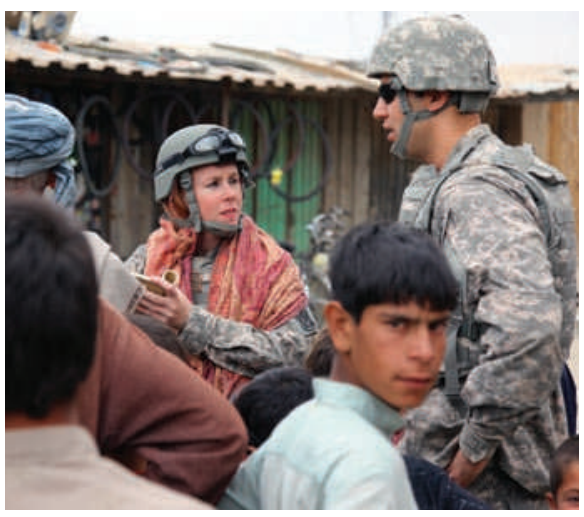

The US Army's beleaguered social-science programme faces an uncertain future.

which often wants to control them.

The programme has also suffered more concrete setbacks. It has struggled to recruit and retain social scientists. Several deployed social scientists have been killed, a translator was kidnapped in January (and later released) and one civilian team member pleaded guilty to voluntary manslaughter after executing an Afghan man who attacked social scientist Paula Loyd last year. Loyd later died of her wounds.

Roberto Gonzalez, an anthropologist and the author of American Counterinsurgency, a book on the HTS, says he is surprised that the leadership shake-up has been so long in coming. "Some argue that the HTS is suffering from poor management and lack of oversight, and that if these problems could be corrected it would be successful," he says. "I disagree. The entire programme is flawed because Human Terrain team members are thrust into an impossible situation in which they are torn between conflicting interests."

Funding for the HTS has increased from US $\$ 10$ million to US\$100 million a year since it began in 2006. But in May, a congressional panel said that it would limit funding until the project had been assessed by the army.

More changes lie ahead. The army has confirmed that it is seeking a new contractor to train Human Terrain teams. Georgia Tech Research Institute in Atlanta, which currently provides training, has decided to end its involvement - but did not give details.

Fondacaro denied that problems with the programme were caused by his leadership, arguing that aspects such as contracting were beyond his control. "The record will show, if anybody cares to look, that the things I was able to manage worked quite well," he said.

Asked about the programme in a meeting with reporters in March, US secretary of the army John McHugh said that he was "neither happy nor unhappy" with the HTS. "Whether it's a long-term solution or one in which we can glean short-term lessons and then move forward is still something we're not able to judge," McHugh said.

Sharon Weinberger

\section{White House stalls oil-slick research}

Plans to distribute monies from BP's ten-year Gulf of Mexico Research Initiative (GRI) have been thrown into turmoil by a last-minute edict from the White House.

On 15 June, BP announced that it would distribute US\$25 million in fast-track funding across three research institutions in its first step towards fulfilling a $\$ 500$-million pledge for high-priority studies to assess environmental damage from the oil spill.

BP had planned to put out a request for proposals for the remaining $\$ 475$ million within days of the announcement and said that large-scale research centres would be established as part of its mission.

But on 16 June, the White House issued a vaguely worded statement that could slow the effort. The press release said that BP would consult with "governors, and state and local environmental and health authorities" to design its long-term monitoring programme within the research initiative.

This has left the future of the initiative uncertain, even to members of an independent advisory panel of six scientists that the company

\section{"The bureaucratic} hurdles are formidable." had set up to evaluate research proposals and decide how the remaining funds would be divided up. The panel includes Rita Colwell, a former director of the US National Science Foundation, and the agency's former assistant director for geosciences Margaret Leinen. On the details of what the programme will entail, Leinen says, "I really am not in a position to talk about it - and I don't think any of us are".

Researchers say that the government mandate could stall the process considerably. "It makes sense to coordinate the Gulf of Mexico research initiative with efforts that are already under way," says Jeffrey Short, an environmental chemist with Oceana, a marine conservation organization based in Washington DC. "But it will be difficult to achieve that coordination in a timely manner. The bureaucratic hurdles are formidable."

BP spokeswoman Elizabeth Ashford says that the company will follow through with its initial $\$ 25$-million commitment. This will be used to establish the interactions between oil, dispersants and the environment, and the ecological conditions on the Gulf Coast before the accident. "The idea was always that this would be independent from BP," says Ashford. "All of that intention is still there. But we do need and intend to be responsive to the White House."

Amanda Mascarelli 